\title{
Sistem Presensi Karyawan Menggunakan Metode Geofencing dab Face Capture Push Notification
}

\author{
Sulyono ${ }^{1}$, Darius Antoni², Jon Heri \\ 1,3 Technical Information Departement, IIB Darmajaya, Lampung, Indonesia \\ 2 Information System Departement, Bina Darma University, Palembang, Indonesia \\ Email: 1sulyono@darmajaya.ac.id, 2dariusantoni@gmail.com, 3 jonheri@darmajaya.ac.id
}

\begin{abstract}
Abstrak
Teknologi mobile adalah teknologi pada telepon seluler atau smartphone. Ini terintegrasi satu sama lain sehingga mereka dapat berkomunikasi dan berbagi informasi di mana saja. Masalah penelitian ini diambil dari beberapa wawancara dengan karyawan mengenai tidak efektifnya proses absensi karyawan pada saat hendak pergi ke kota. Tujuan dari penelitian ini adalah untuk menjelaskan bagaimana sebuah android perangkat memperoleh data lokasi pengguna menggunakan metode pelacakan GPS dengan penyedia GPS dan penyedia jaringan. Data lokasi ini dalam bujur dan Garis Lintang. Hal ini digunakan oleh staf admin untuk memantau posisi karyawan mereka. Itu hasil penelitian ini menyatakan bahwa sistem absensi karyawan berbasis android aplikasi dengan penggunaan layanan berbasis lokasi menggunakan Geofencing dan Face Metode Capture Push Notification mampu memudahkan karyawan untuk melakukan absensi jarak jauh dan mendeteksi posisi perangkat saat melakukan proses kehadiran real-time.
\end{abstract}

Kata Kunci: Presensi, Geofencing, Face Capture Push Notification

\section{PENDAHULUAN}

Mendapatkan Teknologi mobile merupakan teknologi dalam ponsel selular atau smartphone (ponsel pintar) yang bersifat digital. Dengan teknologi ini, semua user terintegrasi satu sama lain sehingga dapat melakukan komunikasi maupun berbagi informasi dimana saja, kapan saja dan siapa saja apabila sudah terkoneksi pada suatu jaringan internet. Perangkat mobile juga telah terdapat berbagai sistem operasi sebagai penunjang majunya teknologi informasi dan komunikasi contohnya sistem operasi android.

Penelitian ini dibentuk untuk meningkatkan kinerja pengguna khususnya seorang karyawan pada perusahaan atau instansi tertentu melakukan absensi secara jarak jauh. Permasalahan yang biasa muncul dari beberapa studi kasus dengan 
karyawan mengenai tidak efektifnya proses absensi karyawan saat hendak dinas keluar kota. Data lokasi ini berbentuk longitude dan latitude yang digunakan oleh admin staff untuk memantau posisi karyawannya. Dalam penelitian ini juga dicatat data posisi setiap kantor ke dalam database yang berbentuk longitude dan latitude sehingga dapat menjadi pembanding paramater jarak antara posisi pengguna android dan posisi kantor tersebut.

Dalam aplikasi ini terdapat Google Maps yang telah dibentuk dengan berbagai batas akses didalamnya sehingga user dapat melihat posisinya sendiri dan dapat melakukan akses absen apabila sudah masuk dalam area akses yang telah terlihat di Google Maps tersebut.

\section{METODE}

\subsection{Metode Penelitian}

a. Kebutuhan Fungsional

Pada tahap ini akan dilakukan analisis kebutuhan fungsional sistem untuk Sistem Presensi Karyawan Menggunakan Metode Geofencing \& Face Capture Push Notification Berbasis Android. Kebutuhan fungsional berisi proses-proses yang harus disediakan oleh sistem. Hasil analisis kebutuhan fungsional antara lain :

a. Super Admin

1) Admin dapat melakukan login.

2) Admin dapat manambah, mengedit, melihat, dan menghapus Data Karyawan, Laporan Presensi, Data Admin, Slider Informasi, dan Data

b. Karyawan riwayat presensi

1) Dapat melakukan login.

2) Dapat melakukan melihat About, Histori, Presensi Masuk, Presensi Keluar, Notifikasi, dan Notif jika ada di area/zona presensi.

3) Dapat melakukan Presensi Masuk, Presensi Keluar dengan lokasi maps karyawan.

b. Kebutuhan Non Fungsional

Kebutuhan non fungsional merupakan batasan layanan atau fungsi yang ditawarkan oleh sistem. Hasil analisis kebutuhan non fungsional Sistem Presensi Karyawan Menggunakan Metode Geofencing \& Face Capture Push Notification Berbasis Android antara lain :

1) Kebutuhan Operasional

Sistem yang dibangun bisa digunakan pada platform sistem operasi Microsoft Windows maupun MacOs 
2) Kebutuhan Keamanan

Aplikasi ini bisa diakses oleh pengguna yang berhak. Sistem aplikasinya dilengkapi password. Sistem seharusnya aman digunakan.

3) Kebutuhan Performansi

Sistem dapat menampung data dalam jumlah yang besar dan sistem seharusnya dapat diakses oleh banyak user secara bersamaan.

4) Kebutuhan Kemudahan Pengguna

Sistem dapat dengan mudah digunakan dan dipelajari. Sistem menggunakan bahasa yang mudah dimengerti serta sistem memiliki tampilan menarik.

5) Kebutuhan Panduan Pengguna

Sistem menyediakan panduan singkat tentang cara meggunakan masingmasing fungsi yang tersedia dalam aplikasi..

\subsection{Rancangan Sistem}

\subsubsection{Arsitektur Sistem}

Arsitektur sistem menjelaskan tentang alur Sistem Presensi Karyawan Menggunakan Metode Geofencing \& Face Capture Push Notification Berbasis Android. Pada aplikasi ini memiliki tiga user, yaitu Super Admin, Dinas dan Warga. Untuk mengetahui hak akses sebagai berikut:

1) Admin terlebih dahulu melakukan login untuk dapat menambah, mengupdate, menghapus data karyawan, data kantor dan data notifikasi.

2) Karyawan terlebih dahulu melakukan login untuk dapat melakukan presensi kehadiran.

3) Dapat melakukan Presensi Masuk, Presensi Keluar dengan lokasi maps karyawan.

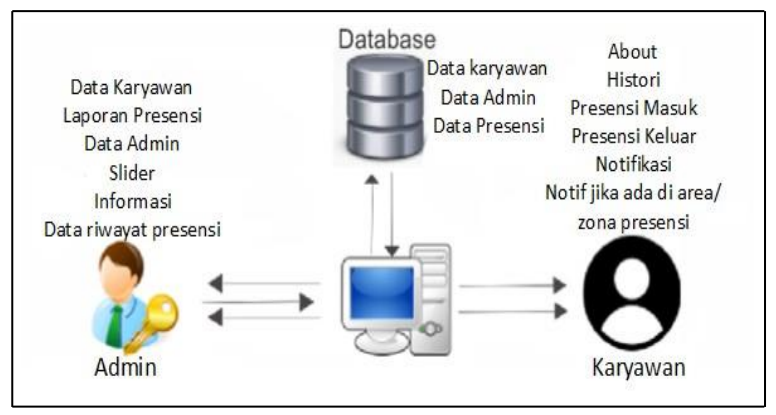

Gambar 1 Arsitektur Sistem Presensi Karyawan Menggunakan Metode Geofencing \& Face Capture Push Notification Berbasis Android 


\subsubsection{Use Case Diagram sistem}

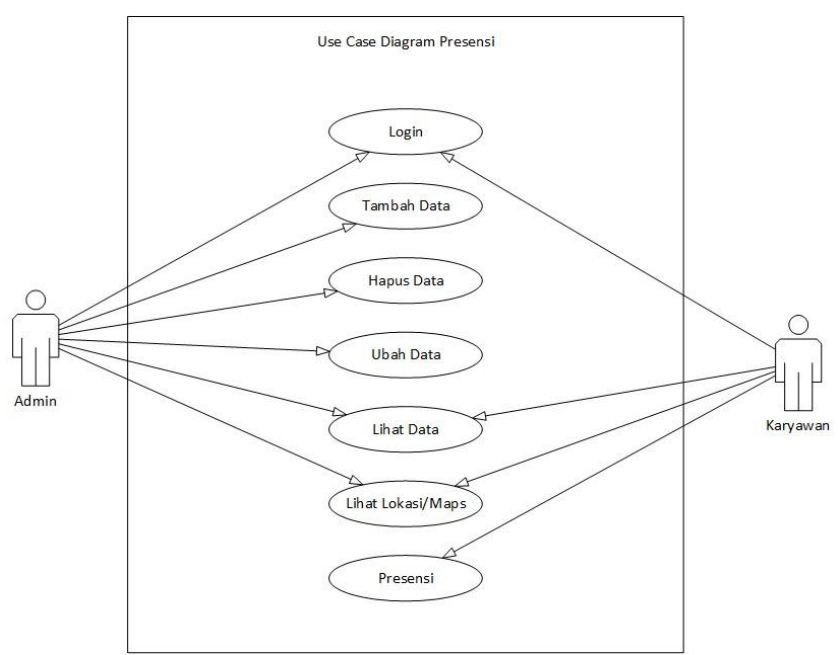

Gambar 2 Use Case Diagram Presensi Karyawan

Pada gambar 2 menggambarkan UseCase Diagram dari sistem yang diajukan.

1) Admin dan Karyawan dapat login sesuai dengan fungsi masing-masing.

2) Admin dapat menambahkan data karyawan, data kantor/perusahaan, dan data notifikasi pengumuman dan slider.

3) Admin dapat menghapus data karyawan, data kantor/perusahaan, data notifikasi pengumuman dan slider.

4) Admin dapat mengedit data karyawan, data kantor/perusahaan dan slider.

\section{HASIL DAN PEMBAHASAN}

\subsection{Hasil Penelitian}

Hasil Penelitian adalah hasil rancangan perangkat lunak dan di implementasikan menjadi sebuah aplikasi Android. Berikut adalah hasil tampilan aplikasi yang telah dibuat.

\subsubsection{Halaman Login Admin}


Halaman login suatu tampilan program yang menampilkan form login yang berupa username dan password yang dapat digunakan pada admin perusahaan yang ditunjukkan pada gambar 3.

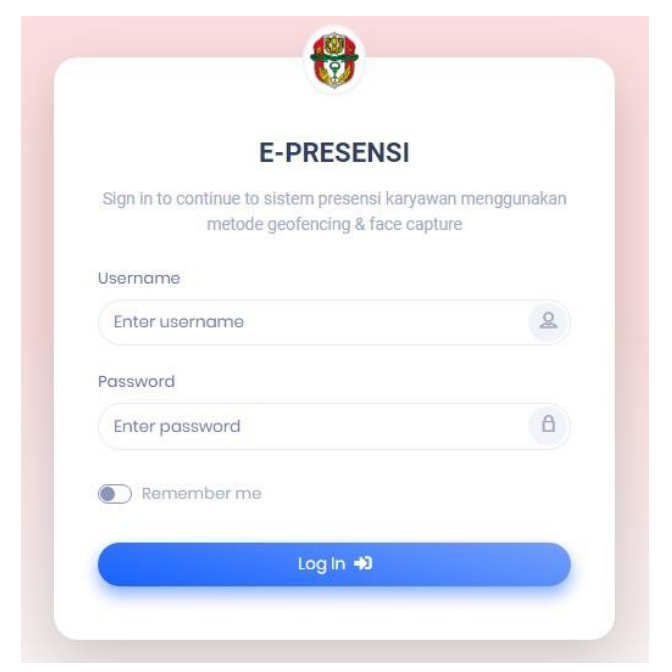

Gambar 3. Halaman Login

\subsubsection{Halaman Utama Admin}

Halaman utama yang menampilkan menu histori presensi, menu karyawan, menu kantor, menu maps karyawan, menu laporan yang didalamnya terdapat sub menu laporan presensi, menu master data yang didalamnya terdapat sub menu data admin, slider dan notifikasi pengumuman yang ditunjukkan pada gambar 4 .

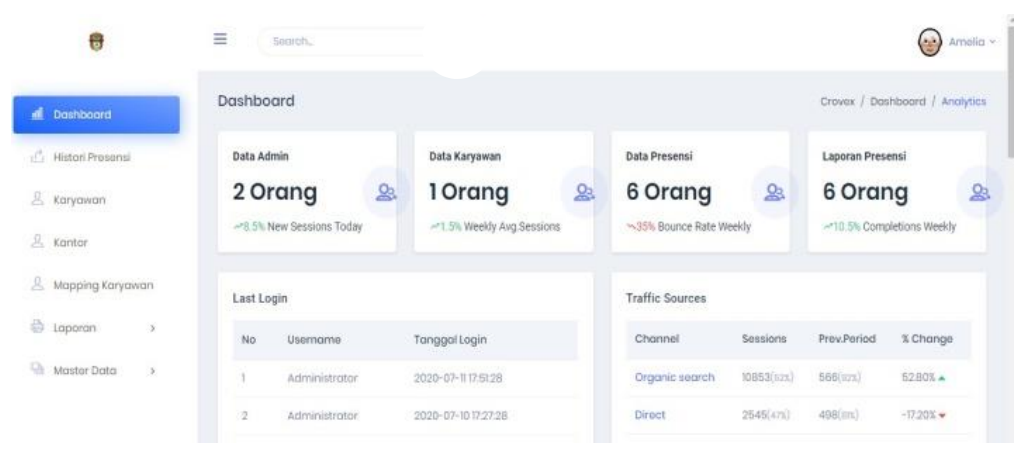




\section{Gambar 4 Halaman Utama Admin}

\subsubsection{Halaman Data Histori Presensi}

Halaman histori presensi yang menampilkan data daftar absen masuk dan keluar didalam perusahaan tersebut yang ditunjukkan pada gambar 5 .

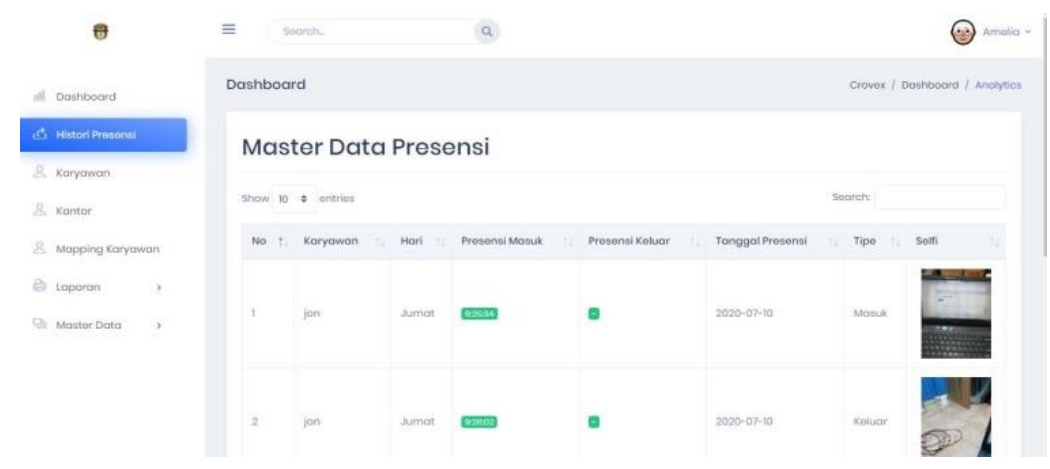

Gambar 5 Halaman Data Histori Presensi

\subsubsection{Halaman Data Mapping Karyawan}

Halaman mapping karyawan untuk halaman maps menampilkan dan memonitoring lokasi karyawan pada saat melakukan absensi secara realtime yang ditunjukkan pada gambar 6 . 
Journal of Information Technology Ampera

Vol. 2, No. 1, 2021 e-ISSN: 2774-2121

https://journal-computing.org/index.php/journal-ita/index

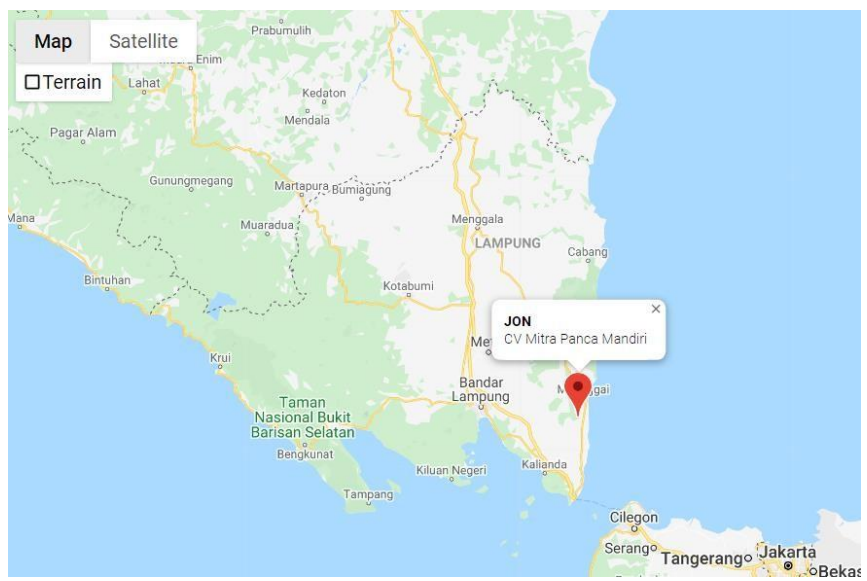

Gambar 6 Halaman Mapping Karyawan

\subsubsection{Halaman Data Laporan Presensi}

Halaman data laporan presensi karyawan menampilkan data absen masuk dan keluar didalam perusahaan tersebut yang kemudian digunakan untuk laporan data dengan export excel atau pdf yang ditunjukkan pada gambar 7 .

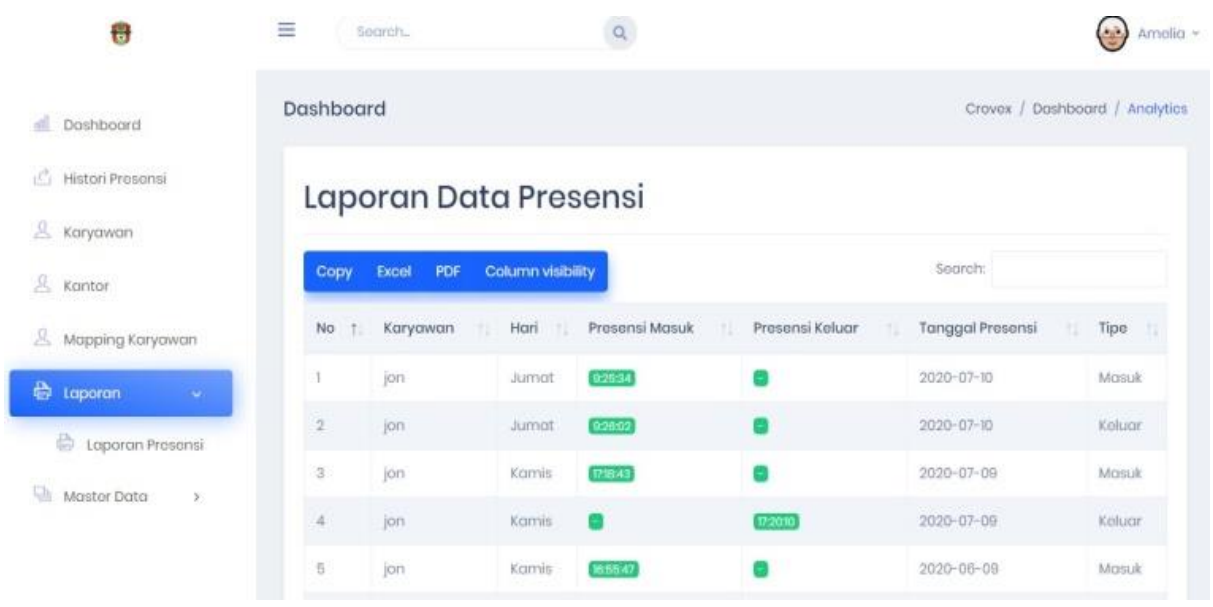

Gambar 7 Halaman Tambah Data Kebutuhan

4. KESIMPULAN 
Berdasarkan hasil analisis, hasil dan pembahasan yang telah dilakukan, serta berdasarkan rumusan masalah yang ada, maka dapat dismpulkan bahwa aplikasi presensi ini menggunakan metode sistem global positioning service dengan metode geofencing \& face capture untuk mendeteksi posisi device saat melakukan proses presensi secara realtime lokasi, aplikasi presensi ini mengimplementasikan dengan berbasis android yang memanfaatkan teknologi geofencing \& face capture dan dapat memonitoring posisi karyawan berada, aplikasi presensi ini berhasil di uji dan dapat dijalankan pada smartphone dengan versi 5.0 Lolipop atau diatasnya, aplikasi presensi ini membutuhkan koneksi internet dan mengaktifkan GPS untuk dapat mengakses sistem aplikasi. Data presensi yang telah dibuat dalam aplikasi presensi ini tercatat kembali dalam web admin dan dapat dipertanggung jawabkan.

\section{DAFTAR PUSTAKA}

[1] Ariyanti, R., Khairil, \& Kanedi, I. (2015). Pemanfaatan Google Maps Api Pada Sistem Informasi Geografis Direktori Perguruan Tinggi Di Kota Bengkulu. Jurnal Media Infotama, 11(2), 121.

[2] Juansyah, A. (2015). Pembangunan aplikasi child tracker berbasis assisted-global positioning system (a-gps) dengan platform android. Jurnal IImiah Komputer dan Informatika (KOMPUTA), 1(1), 1-8.

[3] Rouse, M. (2015) Definition System, http://searchwindowsserver.techtarget.com/definition/system, diakses 15 April 2020.

[4] Rosa A.S dan M. Shalahuddin. (2015). Rekayasa Perangkat LunakTerstruktur dan Berorientasi Objek. Bandung : Informatika Bandung.

[5] Suendri. (2018). Implementasi Diagram UML (Unified Modelling Language) Pada Perancangan Sistem (Studi Kasus: UIN Sumatera Utara Medan). Jurnal IImu Komputer Dan Informatika, 3(1), 1-9. 
[6] Susanty, W., Astari, I. N., \& Thamrin, T. (2019). APLIKASI GIS MENGGUNAKAN METODE LOCATION BASED SERVICE (LBS) BERBASIS ANDROID. Explore: Jurnal Sistem informasi dan telematika, $10(1)$.

[7] Setianni, A., \& Syahputri, R. August). PESONA: SISTEM INFORMASI PEMESANAN SALON ONLINE BERBASIS LOCATION BASED SERVICE. In Prosiding Seminar Nasional Sinergitas Multidisiplin Ilmu Pengetahuan dan Teknologi (Vol. 2, pp. 1-7).

[8] Tullah, R, Tobing, F.A.T, Hadi, A. (2015). Sistem Aplikasi Android untuk Sales Dengan Local Based Service (LBS) Berbasis Client - Server. Tanggerang, Indonesia: STMIK Bina Sarana Global. 